\title{
The Assessment of Depok as Age Friendly City (AFC)
}

\author{
Fatmah, Vita, Dina, Tribudi, Sri Lasmijah \\ Faculty of Public Health, University of Indonesia and Center for Ageing Studies, University of Indonesia, UI \\ Campus, Depok 16424, West Java Province, Indonesia \\ Email: ffatmah@yahoo.com
}

Received May 2014

\section{Abstract}

Depok has a big opportunity to become an age friendly city (AFC) because it has a large number of posbindu, increased elderly population, it does not have yet the pension security for the elderly people, and it does not have yet the number of infrastructure and social facilities needed for the elderly. Before Depok City becomes an age friendly city, an assessment of the eight-dimensional indicators of AFC had been carried out by a team of UI researchers from Center of Ageing Studies in collaboration with the Institute for Survey METER in March 2013. One of the main finding was the presence of the three indicators of AFC in Depok which still lack, they are buildings and open space, housing, and civil participation and employment. The purpose of the study was to assess the public's opinion on the three indicators of AFC that still lack in Depok. The study shows that the majority of people and government as stakeholder assess that Depok is ready to become AFC as long as supported by the government of Depok City with the good coordination with related institutions for the budget and programs prioritizing the interests of the elderly. Moreover, the existence of Komda (Comission Area) of Elderly Depok City can support the establishment of a friendly city towards the elderly. The community prefers to choose the indicators of buildings and open spaces as a top priority for elderly-friendly city rather than chooses the indicators of housing and civil participation and employment for the elderly people. Therefore, hopefully Depok City Government with related institutions can build the building which is elderly-friendly as well as AFC socialization to the government and private sectors in order to achieve rapid implementation of Depok as an AFC.

\section{Keywords}

Age Friendly City, Elderly, Building and Open Space, Housing, Civil Participation and Employment

\section{Introduction}

The increase of life expectancy (life expectancy) has an impact on the increase of elderly population in Indonesia [1]. The increase in the elderly population should be balanced with the efforts to achieve the goal of active aging. Active aging which consists of three main pillars which are income security, health, and a possibility to participate can help to establish an Age Friendly City (AFC). AFC has eight indicators i.e. the 
provision of health facilities, social, environment, communications and information, infrastructure, transportation, legal, and human rights, as well as the combination of the various dimensions [2].

To support the establishment of elderly-friendly community, it needs to be designed a development of AFC, but many cities in Indonesia are not yet elderly-friendly. That fact can be seen that the elderly citizens are still difficult to access public facilities. The real example is that the busway stations are built very high so it is difficult for the elderly to walk through. There are many multi-storey buildings that do not provide the elevators, and that forces the elderly people to use the stairs. There are eight areas require special handling for elderly people, namely health, social, environment, information and communications, infrastructure, transportation, law, and art. In Indonesia, Surabaya City Government as the capital of East Java has had local regulations for elderly care and empowerment [3]. Meanwhile, the Depok suburb is characterized as the wish of regional leaders and organizations to make Depok as AFC.

Depok as one of the buffer cities also has an increase elderly population. It is estimated that there are currently 114,060 people of the total population of 1,570,949 people with life expectancy of 73 years [4]. Therefore, Depok has a great opportunity to be AFC because of the activities of posbindu for elderly people have been running long enough (there are nearly 500 posbindu in Depok), there is not yet the pension security for the elderly, the number of infrastructure and facilities for the elderly, etc. However, those things should be done as the preparations to make Depok as an AFC.

Before Depok becomes the AFC, an assessment study of eight dimensions of AFC indicators conducted by the research team of Center for Ageing Studies-UI in collaboration with the Institute for Survey METER in March 2013. The results of the assessment indicate that the degree of conformity of Depok meet the WHO criteria of AFC of $41.6 \%$. The dimensions of AFC in Depok were communication and information (57\%), as well as community support and health services (55\%). While the dimensions of AFC that still lack in Depok are civic participation and employment of $10 \%$, buildings and open spaces of $32 \%$, and housing of $34 \%$ [5]. Therefore, it is necessary for an in-depth study to assess the elements of what are still needed to be improved as well as recommendations for the improvement of the three elements of the indicators which still lack in Depok. The end result of research is useful for decision-makers including local leaders in preparing Depok to become an AFC.

\section{Method}

Cross-sectional study was used in this study on 125 samples which are spread over 25 villages that are selected through direct interview at their residences by 5 enumerators. Sample criteria were men and women aged over 60 years old and live in the selected villages in Depok, and they ere still healthy and were not dementia/senile. The variables measured in the structured questionnaire covered sociodemographic characteristics; ownership savings, insurance, and valuables assets; social activities outside the house; statements agree or disagree on elements of the three indicators of AFC that still lack in Depok, namely buildings and open spaces; housing; and civic participation and employment. Data processing performed after the questionnaire was completed and collected through a process of editing, verification, and coding answers the questions. Then, they are converted into numbers to be input to the computer to be processed by SPSS version 20 for Windows.

\section{Result}

\subsection{Sociodemographic Characteristics of Respondents}

Figure 1 illustrates the distribution of respondents by sex, age, marital status, and educational background. More than half of the total respondents are female (63.2\%) with a mean age of 64 years old that the youngest of 60 years old and the oldest of 90 years old. The majority of respondents are aged between 60 - 69 years (60.8\%) when it is grouped based on RI Ministry of Health and WHO criteria.

Almost all respondents were muslims (96\%) dominated by Betawi ethnic group (53.6\%) and Java ethnic group (22.4\%), but it was still found parts of Manado, Banjarmasin, and Batak ethnic groups. The comparison of the proportion of respondents who were married (59.2\%) and widows/widowers (40.8\%) was almost the same. Most respondents have the educational background of elementary education (30.4\%) and higher education (29,6\%), but many of them never attended school (24.8\%).

Figure 2 shows that more than three-quarters of respondents were no longer working (80\%), but the rest was 


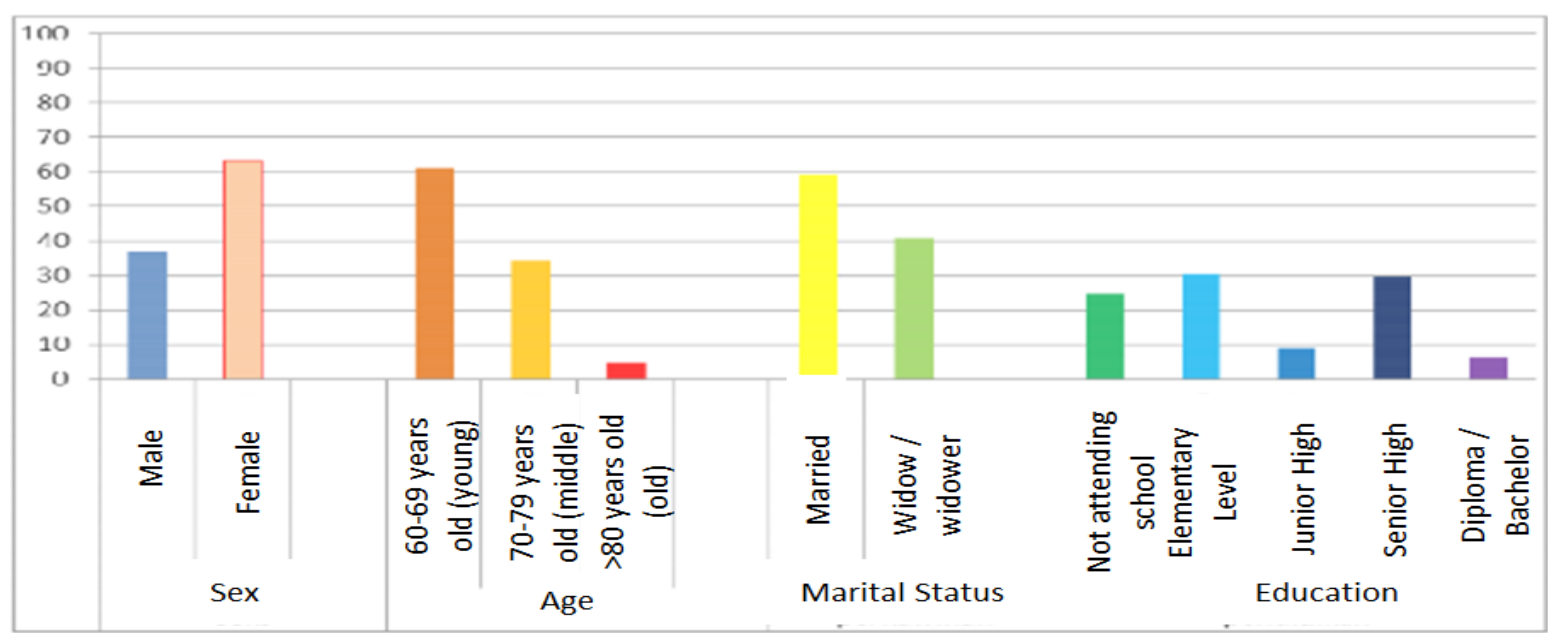

Figure 1. Distribution of respondents by sex, age, marital status, and education background.

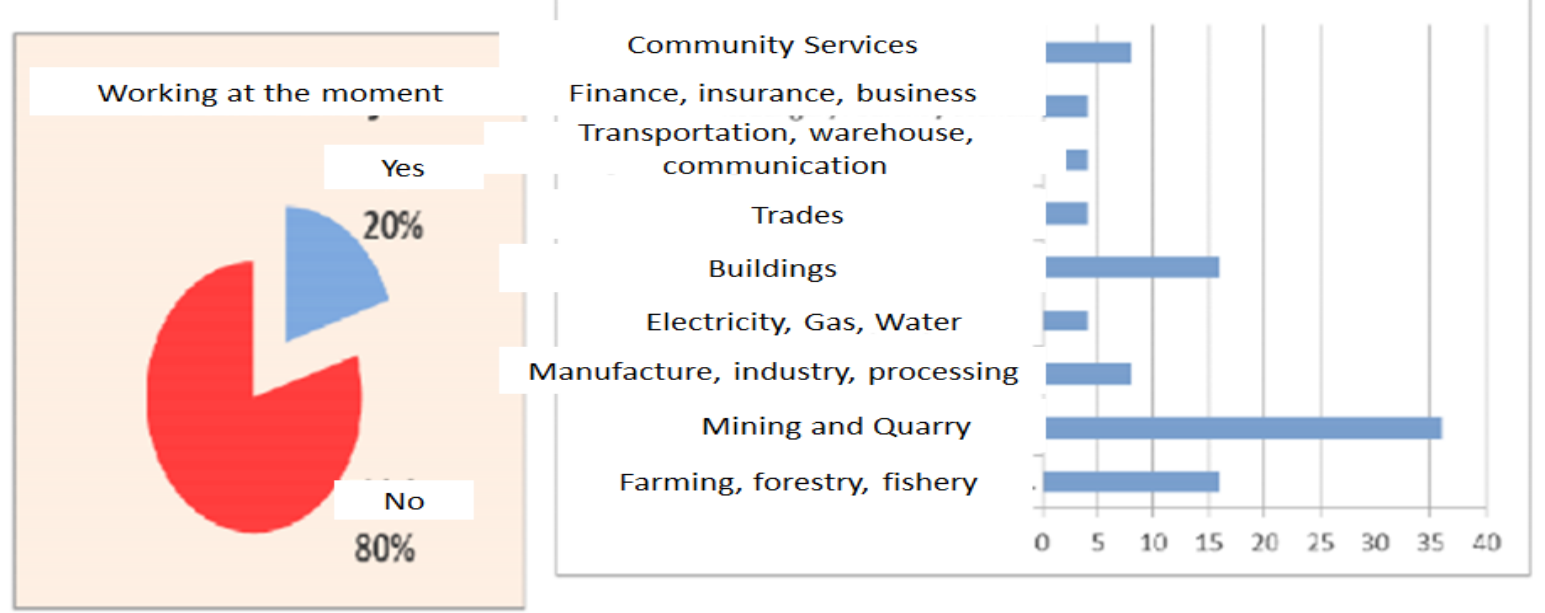

Figure 2. Status and occupation of respondents.

mostly still working in mining and quarry (36\%). But, still there were respondents who work in agriculture (16\%) and work on their own/run their own business (14.4\%).

The mean income of the respondents worked for 3-month activities of Rp 2,500,000, with the lowest income of Rp 200,000, and the highest income of Rp 9,000,000. Only a fifth of respondents who were retired (20\%) with a mean of $\mathrm{Rp} 1.97$ million, with the lowest pension of $\mathrm{Rp} 750,000$, and the highest pension of Rp 4,180,000.

Half of all respondents who have been interviewed stated that their basic need for everyday's meals were still covered by their own children (54.4\%), but some others stated that they provided their basic need of everyday's meals by themselves or their spouse (49.6\%). Meanwhile, half of all respondents said that they still received cash assistance, food, and goods, from their children, the relatives, the government, or from the private sectors within a year (55.2\%) with a mean of Rp 7.182 million.

The status of saving accounts and insurance as well as the type of insurance owned by the respondents can be seen from Figure 3. More than half of the total respondents did not have saving accounts and insurance. While the number of respondents who have insurance generally have JAMKESNAS (37\%), Askes (33\%), and Jamkesda (23\%).

The majority of respondents already hade their own house (80.8\%), electronic equipments like television, refrigerator and rice cooker (67.2\%). Nearly one third of all respondents had a car and a motorcycle (29.6\%) and one third of respondents still owns the land and/or rice field (Figure 4). 


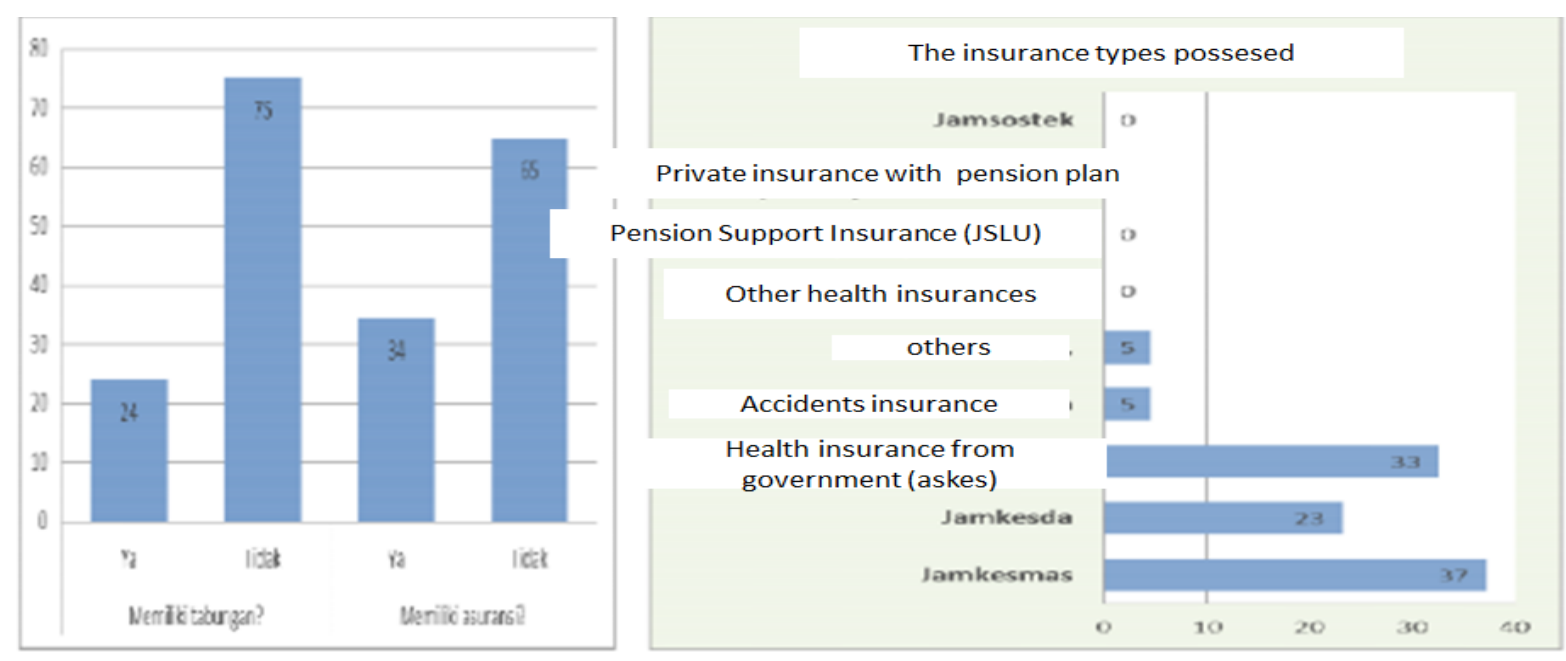

Figure 3. Ownership of saving accounts and insurance.

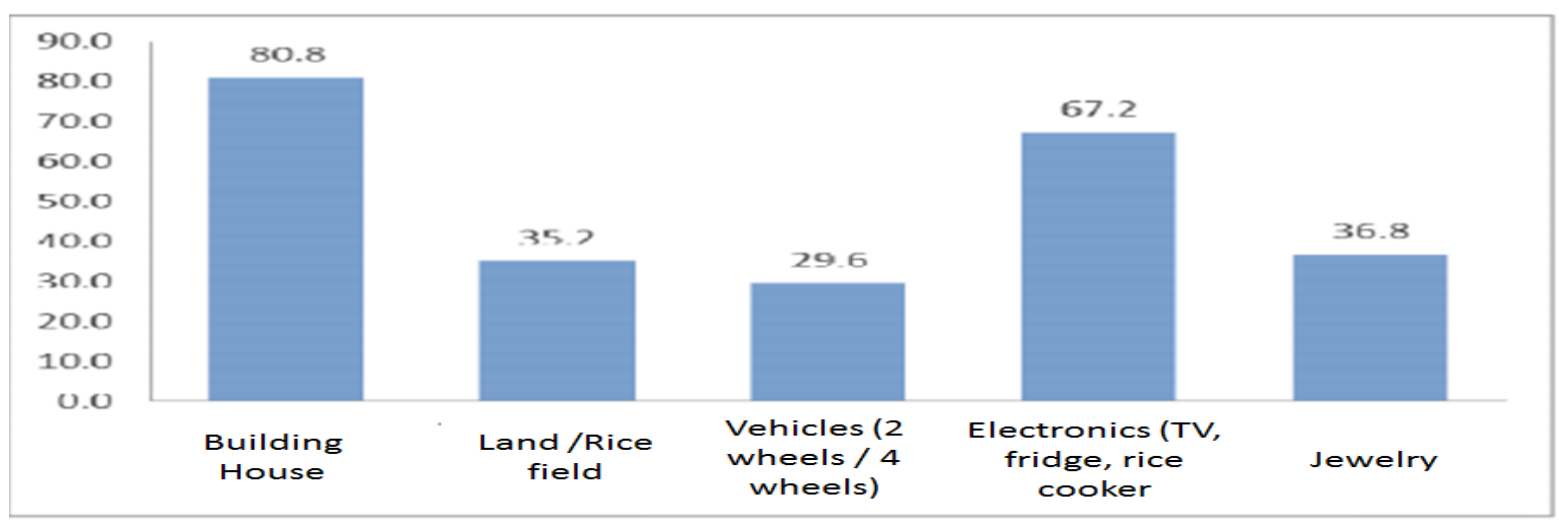

Figure 4. Ownership of goods/asset of respondents [8].

\subsection{Community Events/Social Participation}

When asked whether the respondent were involved in community activities for the last one year, the majority of them stated that they were active in religious activities such as teaching, social gathering (RT, RW, PKK, etc.), community service, and public meetings. The rest of the respondents were active in sports activities, posyandu for toddlers and the elderly, the arts, and youth activities. However, none of the respondents who participated in the savings and loan activities both at RT, RW, villages, and sub-districts (Figure 5).

\subsection{Building and Green Open Space}

The following five conditions approved by more than $50 \%$ of the respondents. The majority of respondents agreed with the statement that the public places in Depok were clean and comfortable (62.4\%), most of the buildings were easily accessible and have a sloping stairs with handrail as well as anti slip floor/not slippery floor (61.6\%), most of the buildings have a clear sign either outside or inside the room, have a toilet and a sitting area adequately (57.6\%), public security in all open spaces are supported by compliance law and public support for personal safety (56.8\%), and public restrooms are clean, well-maintained, easily accessible with a variety of capabilities, well-designed and placed in a location that is easily accessible (55.2\%). Meanwhile, these two elements were only approved by a maximum of $20 \%$ of the respondents which were the special services for the elderly people such as: a separated queue line for the elderly and a special place for the elderly (17.6\%) and the separation of bike lanes and road pavement for pedestrians (11.2\%). The conditions were considered appropriate according to a statement by between $20 \%$ - 50\% of respondents include: street lighting and police patrols in 


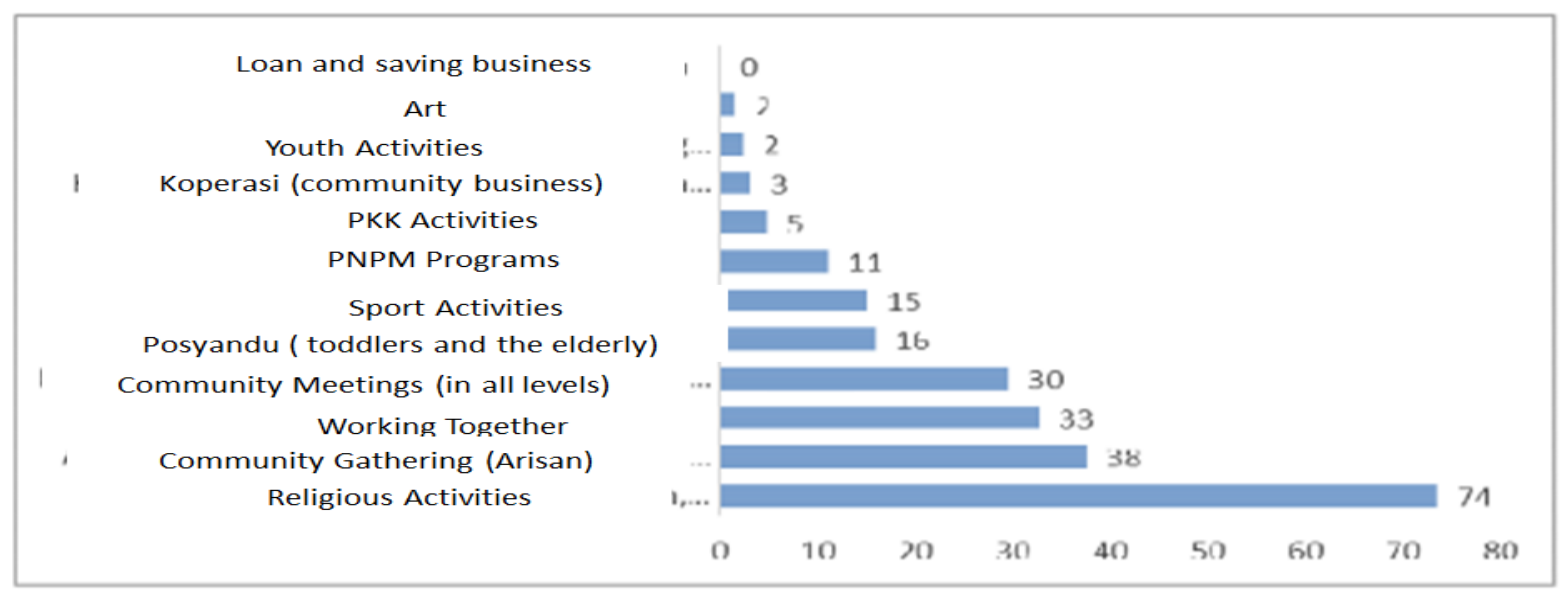

Figure 5. Community service types participated by respondents.

public places are sufficient, green open spaces are well-maintained, audio-visual signs at the crosswalk lights are adequate, pedestrian priority by motorists and motorbikes, the pavement was not slippery and flat with the road surface, and there were special pavement ways for pedestrians.

\subsection{Housing}

Free space in the home for the elderly; the clean and well-maintained rent-house in a secure location; the safe house construction from the weather; adequate number of houses and the affordable cost are some indicator elements on housing which are approved/agreed by most respondents. Approximately $40 \%$ of respondents agreed with the assessment of the average runway, wide entrance for wheel chairs, restrooms, toilet and kitchen in the house have a design that is suitable for the elderly. While the existence of housing developers that understand the needs of the elderly as well as a suitable home for the frail and disabled elderly only approved by a maximum of $20 \%$ of respondents (Figure 7).

\subsection{Civil Participation and Occupation}

None of the respondents agreed on the element conditions of civil participation and employment of elderly people in Depok which was more than the percentage above $50 \%$ because it was only $47.2 \%$ of respondents agreed on the need to improve the quality of work for elderly people in Depok. The rest is less than $25 \%$ of respondents who assess the exact condition of this indicator in terms of training opportunities for the elderly after retirement, the need of recruitment policies on the worker's age, promotion and training for the elderly, and support for the elderly to have an entrepreneurship. In fact, only $11.2 \%$ of respondents who agreed with the lack of job opportunities are flexible with a good income for the elderly.

\subsection{The Priority of Three Indicators That Still Lack in Depok}

When the respondents were asked to choose the prioritized choice of 3 indicators of an AFC that still lack in Depok, most respondents chose buildings and open green spaces (42\%) in the first place. Then, it is followed by the indicator of housing (39\%). Indicator of civil participation and employment was placed as the third choice by most respondents (51\%).

The above findings were consistent with the majority of respondents who give 3 points on indicators of buildings and open green spaces (25\%). One fifth of respondents gives 5 points on the housing (20\%) and followed by 3 points (15.2\%). Civil participation and employment indicators weree given 3 points by one fifth of respondents (23.2\%).

\section{Discussion}

Most of the elderly respondents were female with the age between 60 - 69 years old and the majority of 


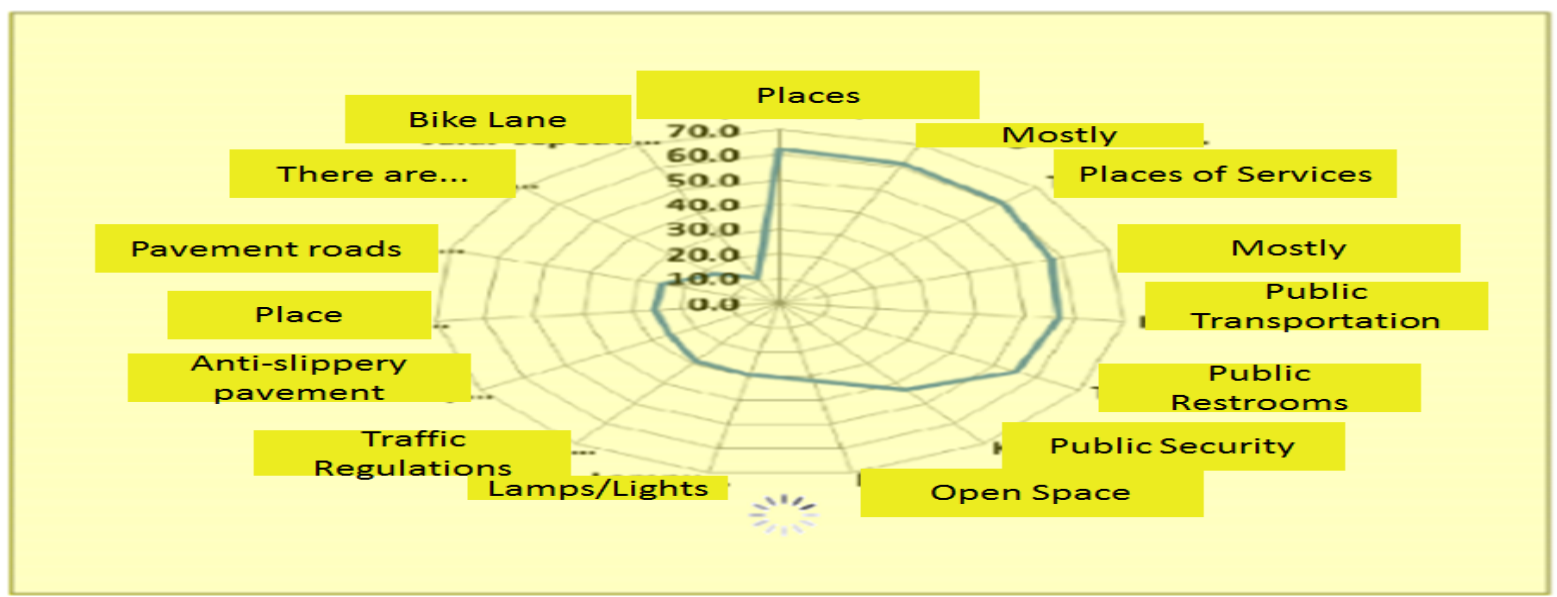

Figure 6. Distribution of agreed statements from respondents on elements of indicators of building and open green space.

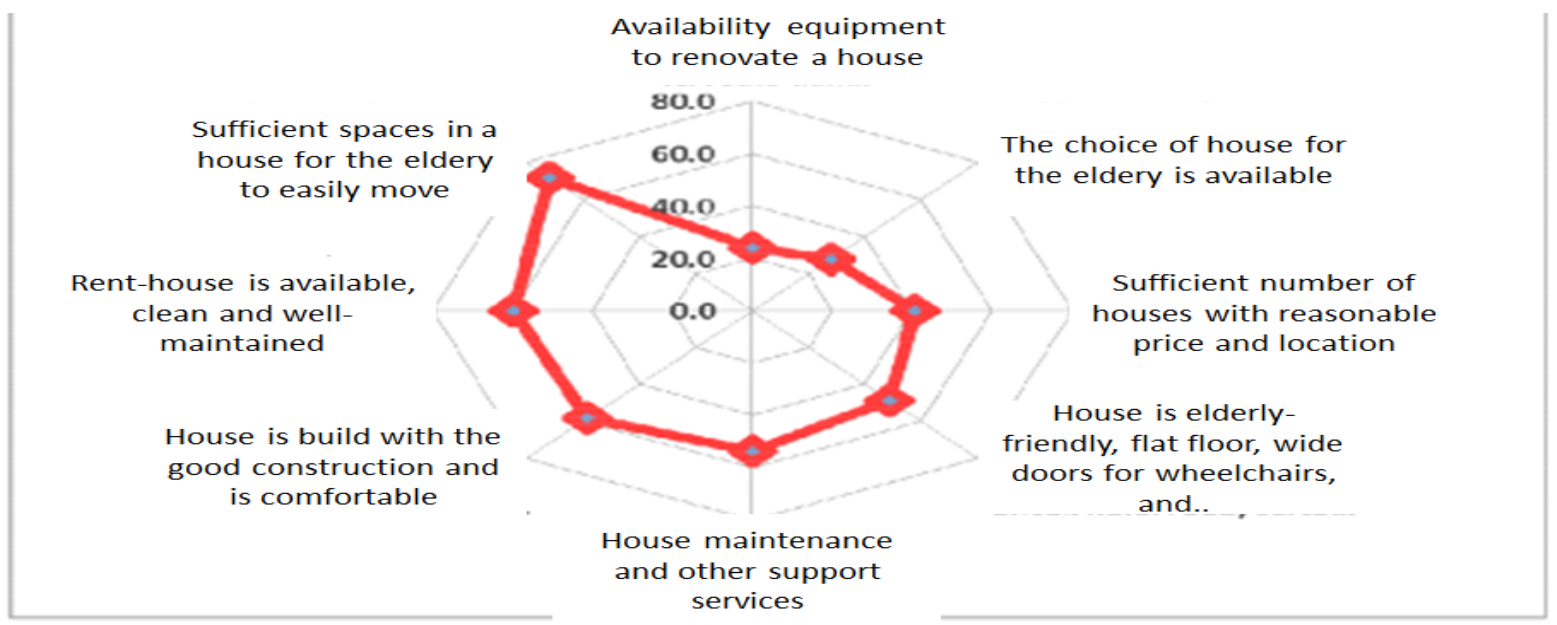

Figure 7. Distribution of agreed statement from the respondents on elements of housing indicators.

respondents had the educational background of primary school. This picture was in line with the profile of the elderly people in Indonesia, most women were in the age range and only have primary school as their educational background [6].

Most respondents stated that Depok was ready and worthy to be an AFC. This was supported by the Mayor of Depok who has a commitment on this by forming Komda (Commision Area) for the elderly people in Depok since 2012. Eight indicators of AFC were in line with the elderly programs Komda (commission area) in the years of 2013-2017 to improve the well-being and quality of life of the elderly people [7]. Besides that, an organization for eldery people, PERGERI Depok, also supports the establishment of AFC [8].

Indicators that still lack in Depok were buildings and open green spaces; housing; and civil participation and employment of the elderly people. The good elements of buildings and open space indicators stated that the level of cleanliness and comfort in public places such as bus stations and railway stations in Depok was good; most buildings already have elderly-friendly stairs with handrails and the floors were not slippery; the presence of signs for direction inside the building; as well as toilets and adequate seats for the elderly. Elements were assessed to be less or almost no special pathway were the availability of service to elderly people; separation of bike lanes with sidewalks; as well as a special place for the elderly pedestrians (Figure 6). This finding was in line with the previous surveys that found the same things of all three of these indicators with the percentage of under $40 \%$.

Freedom of movement within the home for the elderly; rented house for the elderly in a clean condition and in a safe place; as well as the number of reasonably priced homes which were affordable for the elderly are a state of the three parts of the housing indicators in Depok which were approved by the elderly people. Meanwhile, 


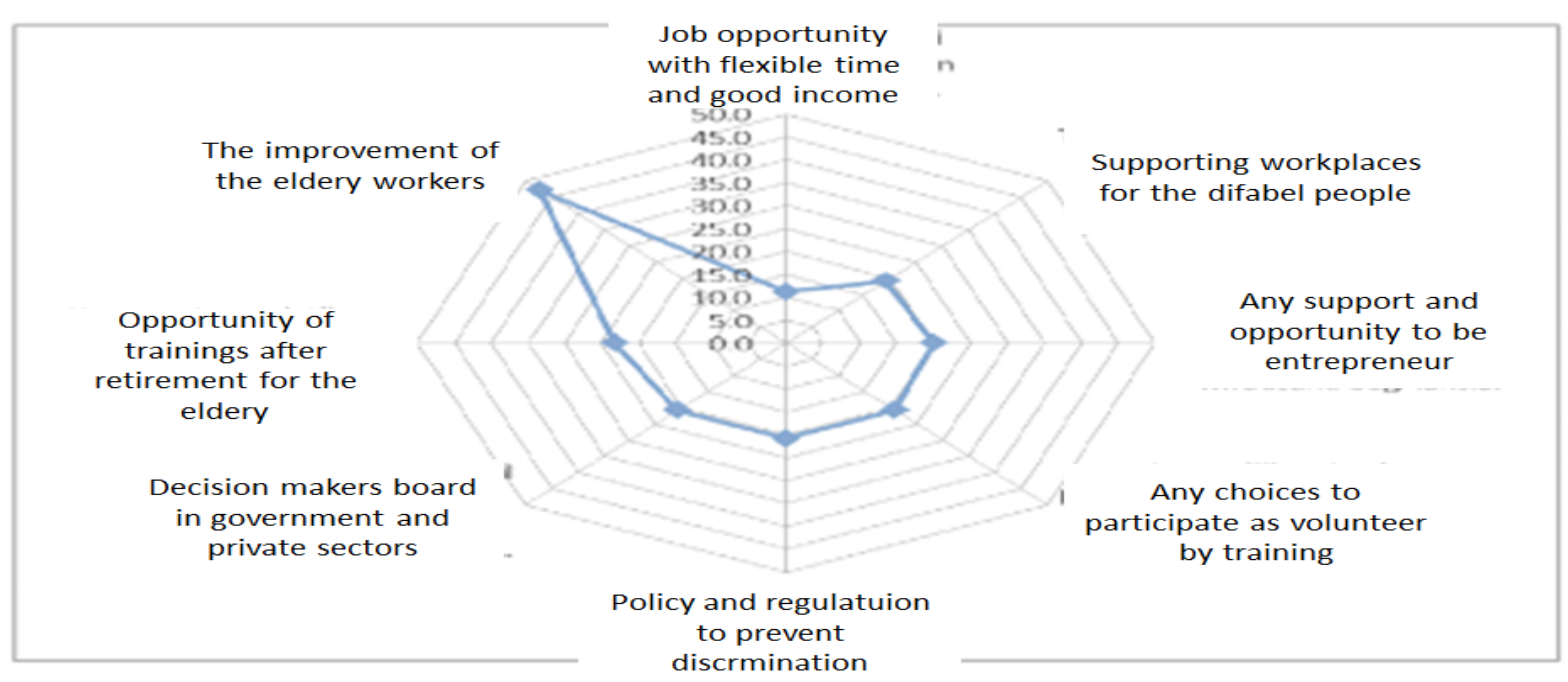

Figure 8. Distribution of agreed statements on elements of civic participation and employment indicators from the respondents.

housing developers understood the needs of the elderly as well as the special home for frail elderly and disabled only one-fifth the maximum approved by all respondents.

Indicators of civil participation and less work were supported by the elderly because of less than half of respondents who approve the necessity of improving the quality of elderly workers. Only a quarter of all respondents who viewed the training needs of elderly post-retirement; the need of the worker's age recruitment policy; promotion for the elderly; and entrepreneurial support for the elderly (Figure 8).

Buildings and open spaces were the main indicators considered important for the elderly. The next was the final indicator of housing and civic participation and employment. This picture can be seen when most respondents gave a value of 3 points on the main indicator. The rest gave a low point for the next two indicators. This was consistent with a study conducted on a group of elderly in Portland, Oregon which states that elderly people were more comfortable being outside in the open air as well as to socialize and interact with other senior citizens [9].

\section{References}

[1] Fatmah (2010) Nutrition for Elderly. Erlangga Publisher, Jakarta.

[2] WHO (2007) Global Age Friendly-Cities: A Guide. WHO, France

[3] Surabaya of Age Friendly City (2012) Gapura XIV, 66, 15.

[4] BPS and Bappeda Depok City (2012) Depok in Number 2012. Bureau of Statistical Center, Depok.

[5] Survey Meter (2013) Report on One Final Step into Dream on Age Friendly City 2030, Survey Meter, Yogyakarta.

[6] Rustika, Woro, R.D. (2000) Profil of Indonesia Elderly People (Analysis of National Health Survey Data 1995). Media Litbang Kesehatan, 10, 16-26.

[7] Depok National Commission of Elderly (2013) Strategic Plan of National Commission of Elderly 2013-2017.

[8] Depok Issues (2014) PERGERI Supported Depok as Age Friendly City Concepts. Dated 27 January 2014. http://depokissue.co/index.php/kabar-kota/berita-kota/kesehatan/2139

[9] Neal, B.M. and Alan DelaTorre (2007) The WHO’s Age Friendly Cities Project in Portland, Oregon Summary Findings 2007. Portland University, Oregon. 
Scientific Research Publishing (SCIRP) is one of the largest Open Access journal publishers. It is currently publishing more than 200 open access, online, peer-reviewed journals covering a wide range of academic disciplines. SCIRP serves the worldwide academic communities and contributes to the progress and application of science with its publication.

Other selected journals from SCIRP are listed as below. Submit your manuscript to us via either submit@scirp.org or Online Submission Portal.
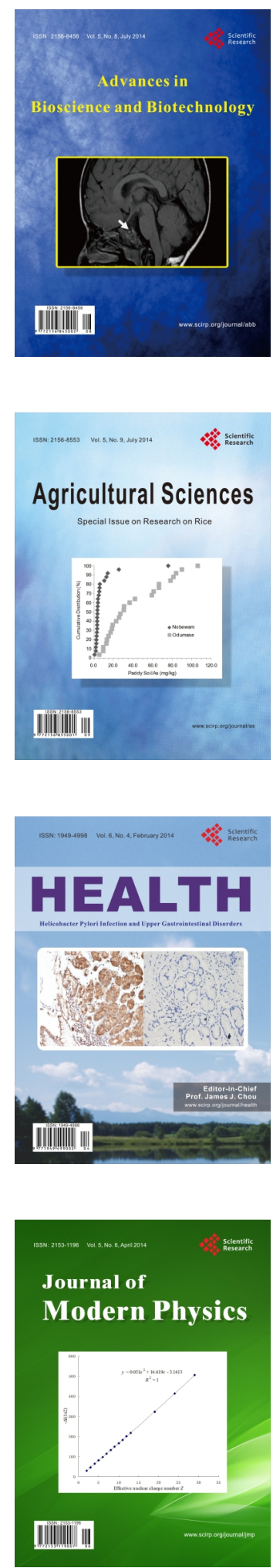
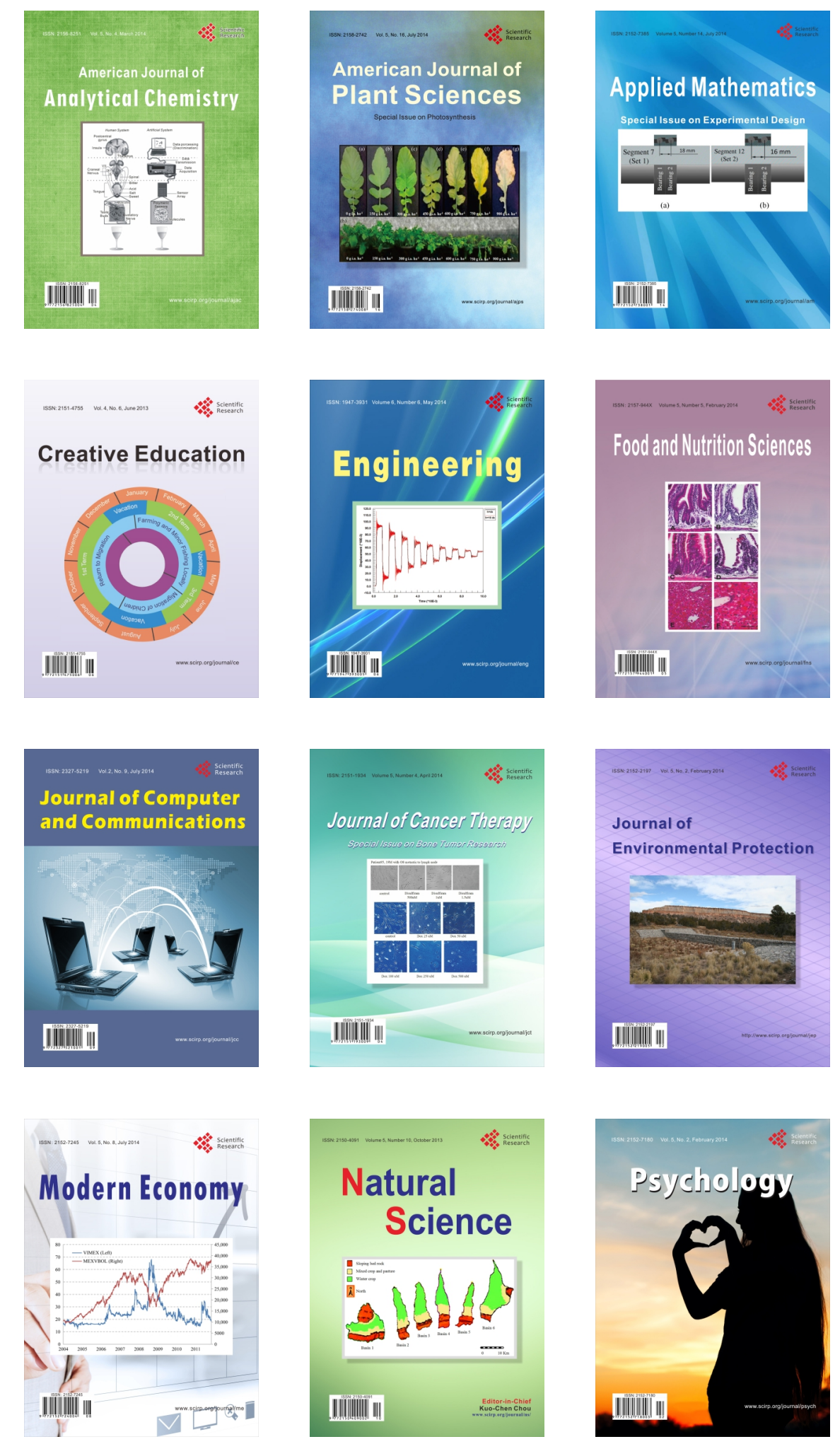